2. DSTU N B A.2.2.5: 2007. Proektuvannya. Nastanova z rozroblennya ta skladannya enerhetychnoho pasporta budynkiv pry novomu budivnytstvi ta rekonstruktsiyi [Designing. Guidelines for the development and assembly of energy passports for buildings under new construction and reconstruction]. K.: Minrehionbud Ukrayiny, 2008. 44 p. (ukr)

3. DSTU B A.2.2-12:2015. Enerhetychna efektyvnist' budivel'. metod rozrakhunku enerhospozhyvannya pry opalenni, okholodzhenni, ventylyatsiyi, osvitlenni ta haryachomu vodopostachanni [Energy efficiency of buildings. Method of calculation of energy heating, cooling, ventilation, lighting and hot water]. K.: Minrehion Ukrayiny. 2015. 205 p. (ukr)

4. DSTU-N B V.1.1-27:2010. Budvel'na klimatolohiya [Construction climatology]. K.: Minrehion Ukrayiny. 2010. 127 p. (ukr)

5. [Electronic resource]: https://energyplus.net/weather-location/europe_wmo_region_6/UKR.

6. [Electronic resource]: https://www.ashrae.org/resources--publications/bookstore/iwec2

7. [Electronic resource]: https://energyplus.net/

8. EnergyPlus: Creating a new-generation building energy simulation program. Crawley D.B., Lawrie L.K., Winkelmann F.C., Buhl W.F., Huang Y.J., Pedersen C.O., Strand R.K., Liesen R.J., Fisher D.E., Wittef M.J., Glazer J. Energy and Buildings. 2001. № 33. Pp. 319-331.

9. [Electronic resource]: https://eosweb.larc.nasa.gov/cgi-bin/sse/grid.cgi?email=tashkent@meta.ua

10. [Electronic resource]: http://www.meteonorm.com

11. W. Beckman, S. Klein, J. Duffy. Calculation of systems of solar heat supply. M.: Energoizdat, 1992.

12. EN 13790:2008. Energy performance of buildings - Calculation of energy use for space heating and cooling. - CEN. European Committee for Standardization, 2008. 53 p.

13. EN ISO 13786:2007. Thermal performance of building component - Dynamic thermal characteristics Calculation methods. - CEN. European Committee for Standardization, 2007. 27 p.

Надійшла 13.11.2017

Received 13.11.2017

УДК 697.1

M.М. Шовкалюк, канд. техн. наук, доц., ORCID 0000-0002-1898-3493

C.В. Зіменко, магістр, ORCID 0000-0003-4151-0931

Національний технічний університет Украӥни «Київський політехнічний інститут імені Ігоря Сікорського»

\title{
АНАЛІЗ ТЕПЛОВТРАТ ЧЕРЕЗ ОГОРОДЖЕННЯ 3 УРАХУВАННЯМ РІЗНИХ МЕТОДІВ ОЦІНКИ ТЕПЛОЗАХИСНИХ ВЛАСТИВОСТЕЙ
}

\begin{abstract}
Метою роботи є дослідження теплових потоків та аналіз теплових втрат з опалювальних приміщень. У статті проаналізовано проблематику питання та взято до розгляду конкретний об'єкт дослідження, розглянуто його конструктивні особливості та конкретні теплопровідні включення за допомогою різних методик розрахунку. Розглянуті методики діючих сучасних стандартів України щодо розрахунку теплозахисних властивостей огороджувальних конструкцій будівлі з врахуванням теплових включень та без них. За результатами дослідження визначено відмінності між методиками, розраховано ключові параметри, визначено відмінності між підходами. Результатом дослідження є висновок щодо значного впливу теплових включень на загальний рівень теплозахисних властивостей огороджувальних конструкиій та важливість правильного вибору методики розрахунку з врахуванням існуючих даних про об'єкт. У висновках визначено, ще методика оцінки теплових втрат з врахуванням теплових включень дозволяє більш точно оцінити теплозахисні властивості ділянки дослідження.
\end{abstract}

Ключові слова: огороджувальні конструкції, тепловий захист, теплопровідні включення.

(C) М.М. Шовкалюк, С.В. Зіменко, 2017 


\section{ISSN 1813-5420 (Print). Енергетика: економіка, технології, екологія. 2017. № 4}

\section{Вступ}

Один з інструментів досягнення енергоефективності у житловому секторі - впровадження заходів на рівні кінцевих споживачів, якими можуть бути як власники приватних будинків, так і ОСББ, ЖБК та інші форми об'єднання. За типами споживачів це можуть бути житлові будівлі, громадські, промислові та ін. Аналіз стану кожного окремого об'єкту можливий лише за умови застосування певних методик оцінювання та аудиту, а також за наявності засобів для інструментального визначення характеристик будівель.

Значну частину житлового фонду (близько 75\%) України було зведено до 90-их років, коли вимоги щодо енергоефективності будівель не були чітко сформовані і рівень теплового захисту огороджень був значно нижче, ніж це встановлено сучасними нормами [1]. Також потрібно враховувати відсутність належного догляду як за будинком, так і за інженерними системами, людський фактор (наприклад, втручання в систему опалення, заміна радіаторів). Для модернізації житлового фонду необхідно проаналізувати ситуацію та рівень енергоефективності кожного будинку, розробити програму фінансування та впровадити заходи 3 енергозбереження. На етапі аналізу спеціаліст визначає стан огороджувальної оболонки будівлі та оцінює рівень їі теплового захисту. На сьогодні є наступні шляхи оцінки цього параметру: розрахунковий та інструментальний. Розрахунковий метод викладено у нормативних документах [1-3], умови мікроклімату в будівлях приймаються за [4]. Досить розповсюдженим $є$ випадки, коли під час енергообстежень будівель коефіцієнти теплопередачі конструкцій аудиторами визначаються як для однорідного огородження, тобто спрощено без урахування теплопровідних включень, хоча навіть для будівель без складних архітектурних форм вплив таких «теплових містків»є досить суттєвим.

При інструментальному визначенні параметрів теплового захисту оболонки будівлі використовують прилад - термогігрометр із зондом для визначення коефіцієнту теплопередачі. Для визначення локальних термічно-неоднорідних ділянок використовується прилад - тепловізор. Порядок, за яким виконуються натурні вимірювання, регулюються сучасними нормативними документами та стандартами [5,6]. Методика для розрахунків показників теплового захисту за допомогою тепловізійного обстеження чітко не сформована, а визначення показників на основі даних, що були отримані при тепловізійній діагностиці, будуть трудомісткими. Тепловізійне обстеження конструкцій є ефективним інструментом для виявлення температурних аномалій.

\section{Мета та завдання}

Метою роботи є порівняння тепловтрат непрозорих огороджень з урахуванням різних методів оцінки теплозахисних властивостей зовнішніх стін, а саме:

- без урахування теплопровідних включень, тобто зовнішні стіни в теплотехнічному розрахунку приймаємо як однорідне непрозоре огородження;

- з урахуванням теплопровідних включень згідно діючих в Україні стандартів [2, 3],

- з урахуванням теплопровідних включень згідно європейського стандарту [7],

- інструментальне визначення характеристик теплового захисту.

Опис об'єкту досліджень

Об'єкт обстеження - окремо розташована житлова багатоквартирна будівля у м. Києві, яка була введена в експлуатацію в 1974 році, територіально належить до I температурної зони згідно [1]. Будівля являє собою 9-поверхову споруду без складних архітектурно-планувальних чи конструктивних рішень.

Таблиця 1 - Характеристика огороджувальних конструкцій

\begin{tabular}{|l|l|}
\hline \multicolumn{1}{|c|}{ Конструктивний елемент } & \multicolumn{1}{|c|}{ Опис } \\
\hline Конструкція зовнішніх стін & $\begin{array}{l}\text { Стіни виконані з червоної будівельної цегли монолітної кладки } \\
\text { товщиною } 640 \text { мм, стіни армовані. Частково присутнє утеплення } \\
\text { зовнішніх стін. }\end{array}$ \\
\hline Внутрішні стіни & Стіни виконані з червоної будівельної цегли монолітної кладки. \\
\hline Міжповерхові перекриття & Перекриття виконані із залізобетонних панелей з пустотами. \\
\hline Дах & $\begin{array}{l}\text { Дах із напівпрохідним горищем. Покриття із ребристих панелей, } \\
\text { покрівля рулонна трьохшарова. }\end{array}$ \\
\hline
\end{tabular}


Продовження табл.1

\begin{tabular}{|c|c|}
\hline Технічне підпілля & Стіни підвалу зі збірних залізобетонних блоків. \\
\hline Світлопрозорі конструкції & $\begin{array}{l}\text { Скління парадних - суцільне, вітражне. Скління південного фасаду є } \\
\text { елементом огороджувальних конструкцій для опалювального об’єму } \\
\text { будівлі. Частина світлопрозорих конструкцій } \quad \text { замінена на } \\
\text { металопластикові склопакети. }\end{array}$ \\
\hline Зовнішні двері & Зовнішні двері під’їзду металеві, обладнані автоматичним доводчиком. \\
\hline
\end{tabular}

Таблиця 2 - Параметри опалювального періоду

\begin{tabular}{|l|l|}
\hline \multicolumn{1}{|c|}{ Розрахунковий параметр } & Значення \\
\hline Тривалість опалювального періоду, $\mathrm{n}_{\mathrm{o}}($ діб $)$ & 176 \\
\hline Середня температура зовнішнього повітря за опалювальний період, $\left.\mathrm{t}_{\mathrm{co}},{ }^{\circ} \mathrm{C}\right)$ & $-0,1$ \\
\hline Кількість градусо-діб опалювального періоду, $\mathrm{D}$ & 3537 \\
\hline
\end{tabular}

Загальний вигляд зовнішніх огороджень будівлі показано на рис.1. Геометричні розміри стінових конструкцій (без урахування цоколю та горища) наведені в табл. 3.

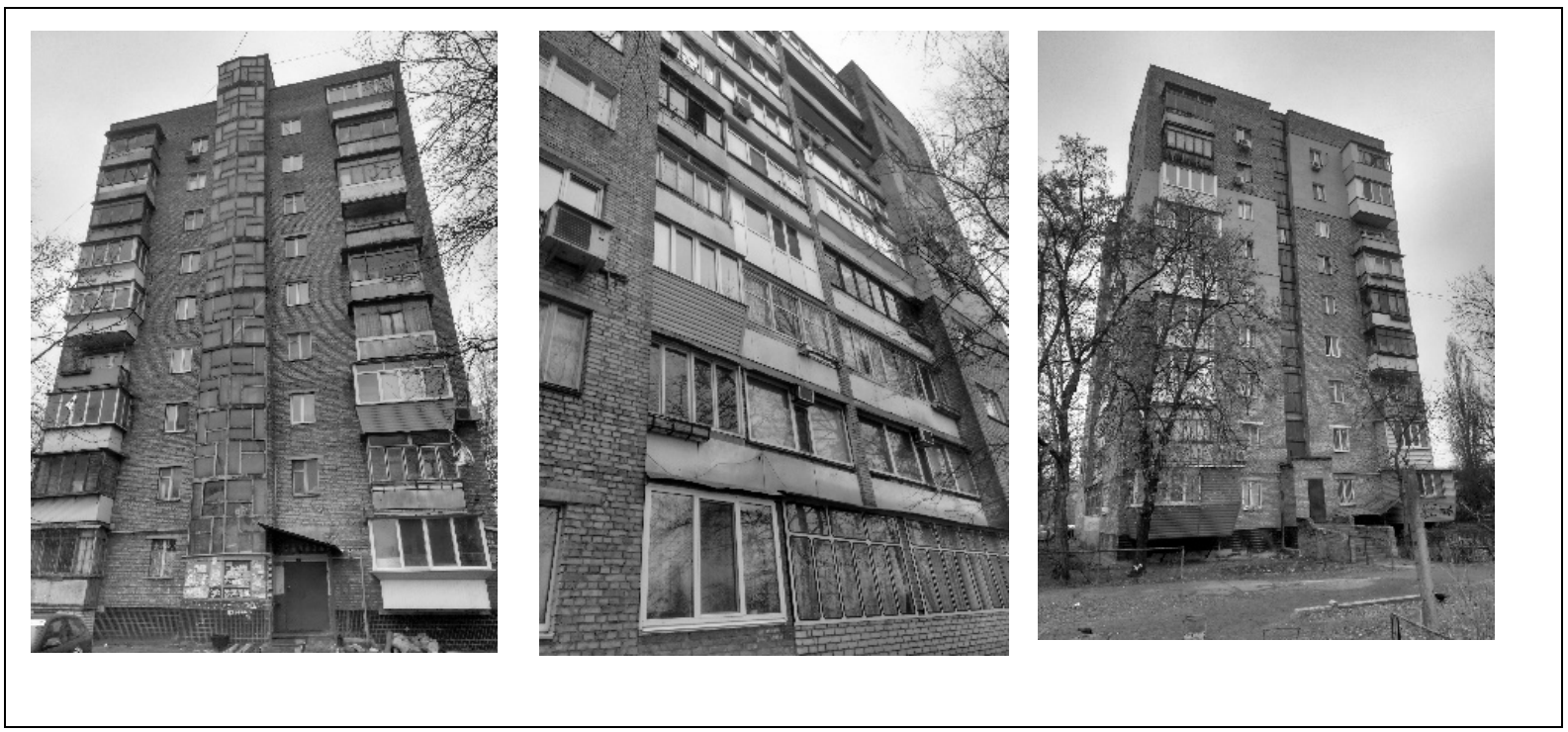

Рисунок 1 - Загальний вигляд зовнішніх стін будівлі

Таблиця 3 - Геометричні розміри зовнішніх стін

\begin{tabular}{|l|l|l|l|l|}
\hline Орієнтація конструкції & Північ & Південь & Схід & Захід \\
\hline Площа конструкції, ${ }^{2}$ & 326 & 374,35 & 509,5 & 509,5 \\
\hline
\end{tabular}




\section{Опис методик розрахунку}

Теплотехнічний розрахунок без урахування теплопровідних включень (розрахунок 1)

Втрати теплоти, Вт·год, через зовнішні стіни визначаються за формулою:

$$
Q_{c m}=\sum_{i} U_{i} A_{i}\left(t_{B H}-t_{C O}\right) \cdot n_{O} \cdot 24,
$$

$t_{6 \mu}$ - розрахункова температура внутрішнього повітря для житлових будівель для теплотехнічних розрахунків, за додатком В стандарту [1] приймаємо $20^{\circ} \mathrm{C}$;

$A i$ - площа зовнішньої стіни, ${ }^{2}$;

$U i=1 / R_{\Sigma i}-$ коефіцієнт теплопередачі огородження, $\left(\mathrm{BT} /\left(\mathrm{M}^{2} \cdot \mathrm{K}\right)\right)$, де $R_{\Sigma i}-$ опір теплопередачі відповідного огородження (утепленої та неутепленої частини зовнішньої стіни), ( $\left.{ }^{2} \cdot \mathrm{K}\right) / \mathrm{B}$.

Опір теплопередачі термічно однорідного непрозорого огородження відповідно до стандарту [2] розраховується за формулою:

$$
R_{\Sigma}=\frac{1}{\alpha_{B}}+\sum_{i=1}^{n} \frac{\delta_{i}}{\lambda_{i}}+\frac{1}{\alpha_{3}}
$$

$\alpha_{b}, \alpha_{3}-$ коефіціснти тепловіддачі внутрішньої і зовнішньої поверхонь огороджувальної конструкції, $\left(\mathrm{BT} / \mathrm{M}^{2} \mathrm{~K}\right)$, приймають за додатком 8 стандарту [2];

$\delta_{i}$ - товщина і-го шару огороджувальної конструкції, (м);

$\lambda_{i}$ - коефіцієнт теплопередачі і-ого шару огороджувальної конструкції, (Вт/м К);

$n$ - кількість шарів огороджувальної конструкції.

Результати розрахунків зведено до табл. 4.

Таблиця 4 - Тепловтрати через огородження без урахування теплопровідних включень

\begin{tabular}{|c|c|c|c|c|}
\hline Продовження табл.4 & & & & \\
\hline Площа конструкції & $A i$ & $\mathrm{M}^{2}$ & 239,2 & 1599,35 \\
\hline Опір теплопередачі & $R_{\Sigma}$ & $\left(\mathrm{M}^{2} \cdot \mathrm{K}\right) / \mathrm{BT}$ & 1,89 & 0,94 \\
\hline Коефіцієнт теплопередачі & $U i$ & $\mathrm{BT} /\left(\mathrm{M}^{2} \cdot \mathrm{K}\right)$ & 0,53 & 1,06 \\
\hline $\begin{array}{c}\text { Втрати теплоти через стіни за } \\
\text { опалювальний період }\end{array}$ & $Q_{c m}$ & кВт·год & 10745,32 & 144456,01 \\
\hline $\begin{array}{l}\text { Сумарні втрати через зовнішні } \\
\text { стіни (без урахування цоколю) }\end{array}$ & $Q_{c m \Sigma}$ & кВт·год & \multicolumn{2}{|c|}{155201,33} \\
\hline $\begin{array}{c}\text { Нормативне значення опору } \\
\text { теплопередачі стін [1] }\end{array}$ & $R_{q \min }$ & $\left(\mathrm{M}^{2} \cdot \mathrm{K}\right) / \mathrm{BT}$ & \multicolumn{2}{|c|}{3,3} \\
\hline
\end{tabular}

\begin{tabular}{|c|c|c|c|c|}
\hline Найменування показника & Познач. & Од. вим. & \multicolumn{2}{|c|}{ Зовнішня стіна } \\
\cline { 3 - 5 } & & & Утеплена & Неутеплена \\
\hline Стінова конструкція & - & - & $\begin{array}{c}\text { Червона цегла 3 } \\
\text { шаром утеплювача } \\
\text { (пінополістирол) } \\
\text { завтовшки 50 мм }\end{array}$ & Червона цегла \\
\hline
\end{tabular}

Визначення трансмісійних тепловтрат 3 урахуванням теплопровідних включень за національним стандартом, розробленим у відповідності до EN 13790 (розрахунок 2)

За стандартом EN 13790 та національною методикою розрахунку [3] теплопередача трансмісією, Втгод, для кожного місяця опалювального періоду визначається окремо за формулою (3):

$$
Q_{t r}=H_{t r, a d j}\left(\theta_{\text {int, set }, H^{-}} \theta_{e}\right) t,
$$

де $H_{t r, a d j}$ - загальний коефіцієнт теплопередачі трансмісією, Вт/К, встановлений для різниці температур всередині-ззовні;

$\theta_{\text {int,set,H }}$ - задана температура зони будівлі для опалення, для житлових приміщень за стандартом [4] для II категорії (нормальний рівень) приймаємо $20^{\circ} \mathrm{C}$; 

${ }^{\circ} \mathrm{C}$;

$\theta_{e}-$ середньомісячна температура зовнішнього середовища, що приймається за дод. А стандарту [3]

$t$ - тривалість опалювального періоду (год).

Для будівлі в цілому значення коефіцієнту теплопередачі трансмісією, Вт/К, повинно бути розраховано згідно стандарту ISO 13789, використовуючи формулу:

$$
H_{t r, a d j}=H_{D}+H_{g}+H_{U}+H_{A},
$$

де $H_{D}$ - узагальнений коефіцієнт теплопередачі трансмісією до зовнішнього середовища, Вт/К;

$H_{g}$ - стаціонарний узагальнений коефіцієнт теплопередачі трансмісією до грунту, Вт/К;

$H_{U}$ - узагальнений коефіцієнт теплопередачі трансмісією через некондиціоновані об'єми, Вт/К;

$H_{A}$ - узагальнений коефіцієнт теплопередачі трансмісією до суміжних будівель, Вт/К.

В ході дослідження будемо враховувати лише втрати через зовнішні стіни, тому визначатимемо лише $H_{D}$ для непрозорих огороджень, а усі інші складові формули (4) приймемо як такі, що дорівнюють нулю. Коефіцієнт теплопередачі трансмісією через стіни визначається за формулою:

$$
H_{D}=b_{t r}\left[\sum_{i} A_{i} \cdot U_{i}+\sum_{k} l_{k} \cdot \psi_{k}+\sum_{j} \chi_{j}\right],
$$

де $A_{i}$ - площа і-го елемента оболонки будівлі, $\left(\mathrm{M}^{2}\right)$;

$U_{i}$ - коефіцієнт теплопередачі і-го елемента оболонки будівлі, $\left(\right.$ Вт/( $\left.\left.{ }^{2} \cdot \mathrm{K}\right)\right)$, що становить $U i=1 / R_{\Sigma i}$, де

$R_{\Sigma i}$ - опір теплопередачі $i$-го елемента оболонки будівлі, $\left(\mathrm{M}^{2} \cdot \mathrm{K} / \mathrm{B} \mathrm{T}\right)$, що визначено за формулою (2);

$\Psi_{k}$ - лінійний коефіцієнт теплопередачі $k$-го лінійного теплопровідного включення, Вт/(м·К);

$l_{k}$ - довжина k-го лінійного теплопровідного включення, м;

$\chi_{j}$ - точковий коефіцієнт теплопередачі $j$-го точкового теплопровідного включення, Вт/К;

$b_{t r}-$ поправочний коефіцієнт, для розрахунку $H_{D}$ приймається $b_{t r}=1$.

Під час проведення енергетичного обстеження багатоповерхової будівлі, що є об'єктом дослідження, були визначені теплопровідні включення для зовнішніх стін і за стандартом [2] визначено лінійні і точкові коефіцієнти теплопередачі огороджень, результати зведено до таблиці 5.

\begin{tabular}{|c|c|c|c|c|}
\hline $\begin{array}{c}\text { Найменування теплопровідного } \\
\text { включення }\end{array}$ & $\begin{array}{c}\text { Довжина, } \\
l_{k}, \mathrm{~m}\end{array}$ & $\begin{array}{l}\text { Кількість, } \\
\text { шт. }\end{array}$ & $\begin{array}{c}\text { Лінійний } \\
\text { коефіцієнт } \\
\text { теплопередачі, } \\
\Psi_{k}, \\
\text { Вт/(м К) } \\
\end{array}$ & $\begin{array}{c}\text { Точковий } \\
\text { коефіцієнт } \\
\text { теплопередачі, } \\
\chi_{j}, \mathrm{Bт} / \mathrm{K}\end{array}$ \\
\hline Віконний відкос в зоні перемички & 1,5 & 35 & 0,063 & 一 \\
\hline Віконний відкос в зоні підвіконня & 1,5 & 35 & 0,035 & - \\
\hline $\begin{array}{l}\text { Вузол кутового сполучення зовнішніх } \\
\text { стін із цегли }\end{array}$ & 27 & 4 & 0,142 & - \\
\hline $\begin{array}{l}\text { Вузол примикання зовнішніх стін із } \\
\text { цегли до балконного перекриття }\end{array}$ & 2,2 & 36 & 0,833 & 一 \\
\hline $\begin{array}{l}\text { Віконний відкос в } \\
\text { примикання }\end{array}$ & 1,4 & 70 & 0,049 & 一 \\
\hline $\begin{array}{l}\text { Вузол примикання зовнішніх стін і3 } \\
\text { цегли до міжповерхового перекриття }\end{array}$ & 90 & 8 & 0,087 & - \\
\hline \begin{tabular}{|lllr} 
Вузол & \multicolumn{2}{c}{ влаштування } & \multicolumn{2}{c}{ пластикового } \\
дюбеля & 3 & металевим & стрижнем для \\
кріплення & теплоізоляційного шару в \\
фасадній & системі 3 & опорядженням \\
штукатурками &
\end{tabular} & 一 & 1673 & - & 0,005 \\
\hline
\end{tabular}

Таблиця 5 - Теплопровідні включення зовнішніх стін будівлі

Під час розрахунків окремо визначався коефіцієнт теплопередачі $U_{i}$ для утепленої та неутепленої частини зовнішньої стіни, далі за формулою (5) визначався коефіцієнт теплопередачі трансмісією через 
зовнішні стіни, потім за формулою (3) для кожного місяця опалювального періоду розраховувалося теплопередача трансмісією.

Для визначення втрат теплоти зовнішніх стін за опалювальний період $Q_{t r},($ Вт·год)/рік, помісячні результати підсумовувалися. Результати розрахунків зведено до таблиці 6.

Таблиця 6 - Тепловтрати через огородження з урахуванням теплопровідних включень за національним стандартом ДСТУ Б А.2.2-12:2015, розробленим у відповідності до ЕN 13790

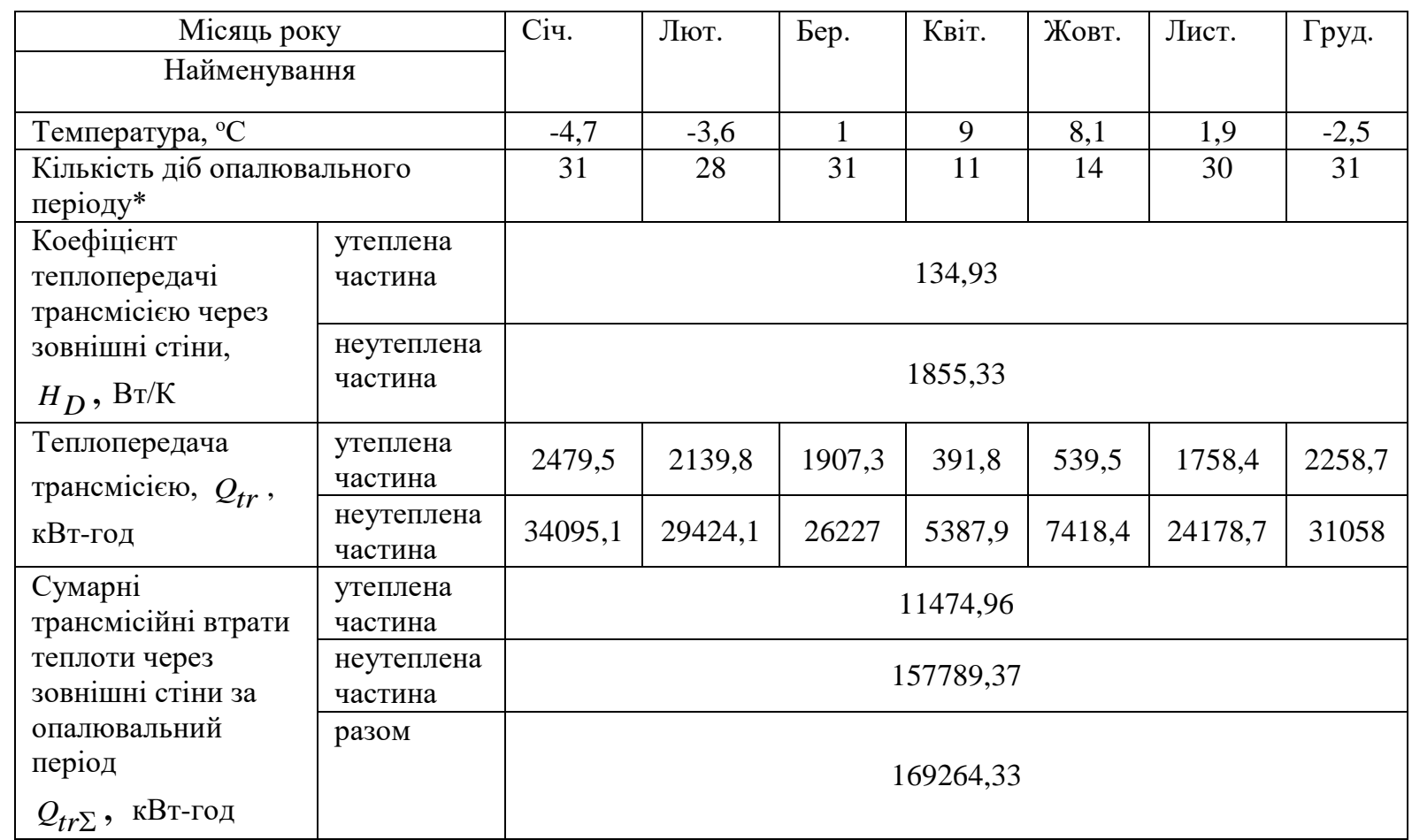

* Примітка: дати переходу середньої добової температури повітря через $8^{\circ} \mathrm{C}$ восени та навесні (дати початку та закінчення опалювального періоду) прийнято за табл.3 ДСТУ-Н Б В.1.1 - 27:2010 «Будівельна кліматологія», для м.Києва 3 17.X по 11.IV.

Розрахунок трансмісійних тепловтрат 3 урахуванням теплопровідних включень згідно європейського стандарту EN 12831 (розрахунок 3)

Відповідно до європейського стандарту EN 12831 [7] визначення тепловтрат за рахунок теплопередачі з урахуванням теплових мостів може проводитися за спрощеним методом визначення втрат теплоти за рахунок теплопередачі. Він полягає в коригуванні значення коефіцієнта теплопередачі за наступною формулою:

$$
U_{k c}=U_{k}+\Delta U_{t b}
$$

де $U_{k c}$ - скоригований коефіцієнт теплопередачі ділянки будівлі з урахуванням лінійних теплових мостів, $\left(\mathrm{BT} /\left(\mathrm{M}^{2} \cdot \mathrm{K}\right)\right)$;

$U_{k}$ - коефіцієнт теплопередачі елемента будівлі, $\left(\mathrm{BT} /\left(\mathrm{m}^{2} \cdot \mathrm{K}\right)\right)$;

$\Delta U_{t b}-$ коригуючий коефіцієнт, що залежить від типу елемента будівлі та береться з додатку до стандарту, $\left(\mathrm{BT} /\left(\mathrm{M}^{2} \cdot \mathrm{K}\right)\right)$.

Значення коригуючого коефіцієнту для огороджень досліджуваної будівлі визначено за

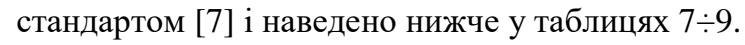

Таблиця 7 - Коригувальний коефіцієнт $\Delta U_{t b}$ для вертикальних елементів будинку

\begin{tabular}{|c|c|c|}
\hline $\begin{array}{c}\text { Кількість перекриттів, що } \\
\text { перетинають теплоізоляцію }\end{array}$ & $\begin{array}{c}\text { Кількість стін, що } \\
\text { перетинаються }\end{array}$ & $\begin{array}{c}\Delta U_{t b}\left(\frac{\mathrm{BT}}{\mathrm{M}^{2} \cdot \mathrm{K}}\right), \text { при об’ємі простору } \\
>100 \mathrm{M}^{3}\end{array}$ \\
\hline 0 & 2 & 0,05 \\
\hline \hline
\end{tabular}


Таблиця 8 - Коригувальний коефіцієнт $\Delta U_{t b}$ для горизонтальних елементів будинку

\begin{tabular}{|l|l|c|c|}
\hline \multicolumn{3}{|c|}{ Елемент будинку } & $\Delta U_{t b}\left(\frac{\mathrm{Bт}}{\mathrm{m}^{2} \cdot \kappa}\right) \cdot$ \\
\hline $\begin{array}{l}\text { Важка підлога (бетон } \\
\text { тощо) }\end{array}$ & $\begin{array}{l}\text { Кількість сторін, що контактують із } \\
\text { зовнішнім середовищем }\end{array}$ & 4 & 0,2 \\
\hline
\end{tabular}

Таблиця 9 - Коригувальний коефіцієнт $\Delta U_{t b}$ для прорізів

\begin{tabular}{|c|c|}
\hline Площа елемента будинку, $\mathrm{M}^{2}$ & $\Delta U_{t b}\left(\frac{\mathrm{BT}}{\mathrm{m}^{2} \cdot \mathrm{K}}\right) \cdot$ \\
\hline$>20$ & 0,1 \\
\hline
\end{tabular}

Теплопередача трансмісією, Вт-год, для кожного місяця опалювального періоду визначалася окремо за формулою (3), де загальний коефіцієнт теплопередачі трансмісією для зовнішніх огороджень, $\mathrm{BT} / \mathrm{K}$, розраховувався наступним чином:

$$
H_{t r, a d j}=H_{D}=A \cdot U_{k c},
$$

де $A$ - площа зовнішніх стін (утепленої та неутепленої частини), м².

Результати розрахунків зведено до таблиці 10.

Таблиця 10 - Тепловтрати через огородження з урахуванням теплопровідних включень за стандартом EN 12831

\begin{tabular}{|c|c|c|c|c|c|c|c|}
\hline Місяць року & \multirow[t]{2}{*}{ Січ. } & \multirow[t]{2}{*}{ Лют. } & \multirow[t]{2}{*}{ Бер. } & \multirow[t]{2}{*}{ Квіт. } & \multirow[t]{2}{*}{ Жовт. } & \multirow[t]{2}{*}{ Лист. } & \multirow[t]{2}{*}{ Груд } \\
\hline Найменування & & & & & & & \\
\hline Температура, ${ }^{\circ} \mathrm{C}$ & $-4,7$ & $-3,6$ & 1 & 9 & 8,1 & 1,9 & $-2,5$ \\
\hline
\end{tabular}

Продовження табл. 10

\begin{tabular}{|c|c|c|c|c|c|c|c|c|}
\hline \multicolumn{2}{|c|}{$\begin{array}{l}\text { Кількість діб опалювального } \\
\text { періоду* }\end{array}$} & 31 & 28 & 31 & 11 & 14 & 30 & 31 \\
\hline \multirow{2}{*}{$\begin{array}{l}\text { Скоригований } \\
\text { коефіцієнт } \\
\text { теплопередачі } \\
\text { ділянки } \\
\text { будівлі } 3 \\
\text { урахуванням } \\
\text { лінійних } \\
\text { теплових } \\
\text { мостів, } U_{k c} \text {, } \\
\text { Вт/(м²· })\end{array}$} & $\begin{array}{l}\text { утеплена } \\
\text { частина }\end{array}$ & \multicolumn{7}{|c|}{0,88} \\
\hline & $\begin{array}{l}\text { неутеплена } \\
\text { частина }\end{array}$ & \multicolumn{7}{|c|}{1,41} \\
\hline \multirow{2}{*}{$\begin{array}{l}\text { Коефіцієнт } \\
\text { теплопередачі } \\
\text { трансмісією } \\
\text { через зовнішні } \\
\text { стіни, } H_{D}, \\
\text { Вт/K }\end{array}$} & $\begin{array}{l}\text { утеплена } \\
\text { частина }\end{array}$ & \multicolumn{7}{|c|}{210,28} \\
\hline & $\begin{array}{l}\text { неутеплена } \\
\text { частина }\end{array}$ & \multicolumn{7}{|c|}{2261,21} \\
\hline $\begin{array}{l}\text { Теплопередача } \\
\text { трансмісією, } \\
Q_{t r}, \text { кВт-год }\end{array}$ & $\begin{array}{l}\text { утеплена } \\
\text { частина }\end{array}$ & 3864,3 & 3334,9 & 2972,5 & 610,7 & 840,8 & 2740,4 & 3520,1 \\
\hline
\end{tabular}


Продовження табл. 10

\begin{tabular}{|c|c|c|c|c|c|c|c|c|}
\hline & $\begin{array}{l}\text { неутеплена } \\
\text { частина }\end{array}$ & 41553,8 & 35861,0 & 31964,4 & 6566,5 & 9041,2 & 29468,1 & 37852,6 \\
\hline $\begin{array}{l}\text { Сумарні } \\
\text { трансмісійні } \\
\text { втрати теплоти }\end{array}$ & $\begin{array}{l}\text { утеплена } \\
\text { частина }\end{array}$ & \multicolumn{7}{|c|}{17883,6} \\
\hline $\begin{array}{l}\text { стіни за } \\
\text { опалювальний } \\
\text { період }\end{array}$ & $\begin{array}{l}\text { неутеплена } \\
\text { частина }\end{array}$ & \multicolumn{7}{|c|}{192307,7} \\
\hline $\begin{array}{l}Q_{t r \Sigma}, \quad к B \mathrm{~T}- \\
\text { год }\end{array}$ & разом & \multicolumn{7}{|c|}{ 210191,3 } \\
\hline
\end{tabular}

\section{Інструментальне визначення характеристик теплового захисту будівель}

Дослідження проводилися комплектом testo 635-2 (термогігрометр із виносним зондом), що дозволяє при певних значеннях коефіцієнту тепловіддачі на внутрішній та зовнішній поверхнях огородження визначати температури поверхні стіни у трьох точках, внутрішню та зовнішню температури повітря та коефіцієнт теплопередачі. Порядок проведення вимірювань та фіксації даних наводиться у стандарті [6]. Випробування в натурних умовах проводять у періоди року, коли існує температурний напір не менший ніж 15 градусів. Температура повітря в приміщенні підтримувалася за допомогою системи опалення будівлі, вимірювання проводилися на ділянці неутепленої частини огородження, захищеній від теплового та сонячного впливу 3 фіксацією значення у пам'ять пристрою кожні три години. Для вимірювання використовувалося наступне обладнання: ноутбук, зонд для вимірювання температури поверхні конструкції в трьох точках, радіозонд для проведення вимірювань зовнішніх параметрів. Результати вимірювань наведено на рис. 2.

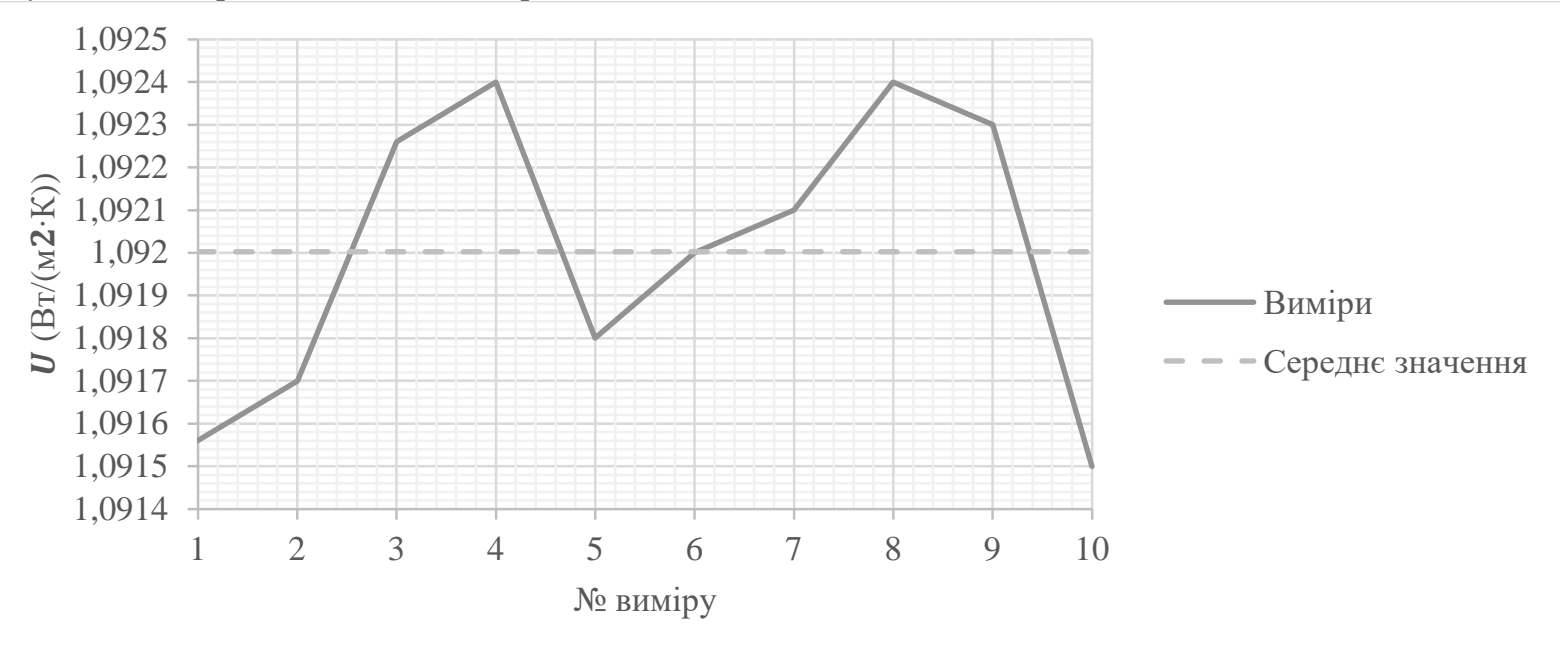

Рисунок 2 - Вимірювання коефіцієнта теплопередачі неутепленої ділянки зовнішніх стін

\section{Узагальнення результатів дослідження}

Порівнюємо результати розрахунків тепловтрат та інструментальні виміри (див. табл.11). 
Таблиця 11 - Порівняння результатів

\begin{tabular}{|c|c|c|c|c|c|}
\hline Парам & & Розрахунок 1 & Розрахунок 2 & Розрахунок 3 & $\begin{array}{c}\text { Інструментальні } \\
\text { виміри }\end{array}$ \\
\hline $\begin{array}{c}\text { Коефіцієнт } \\
\text { теплопередачі }\end{array}$ & $\begin{array}{l}\text { утеплена } \\
\text { частина }\end{array}$ & $\mathrm{U}=0,53$ & - & $U_{k c}=0,88$ & - \\
\hline $\begin{array}{c}\text { огороджень } \\
\text { Вт/(м²· })\end{array}$ & $\begin{array}{c}\text { неутеплена } \\
\text { частина }\end{array}$ & $\mathrm{U}=1,06$ & - & $U_{k c}=1,41$ & $\mathrm{U}=1,092$ \\
\hline $\begin{array}{c}\text { Коефіцієнт } \\
\text { теплопередачі }\end{array}$ & $\begin{array}{l}\text { утеплена } \\
\text { частина }\end{array}$ & - & 134,93 & 210,28 & - \\
\hline $\begin{array}{c}\text { через зовнішні } \\
\text { стіни, } H_{D}, \\
\text { Вт/К }\end{array}$ & $\begin{array}{c}\text { неутеплена } \\
\text { частина }\end{array}$ & - & 1855,33 & 2261,21 & 2007,7 \\
\hline $\begin{array}{l}\text { Втрати теплоти } \\
\text { через зовнішні }\end{array}$ & $\begin{array}{l}\text { утеплена } \\
\text { частина }\end{array}$ & 10745,32 & $Q_{t r}=11474,9$ & $Q_{t r}=17883,6$ & - \\
\hline $\begin{array}{c}\text { опалювальний } \\
\text { період, кВт·год }\end{array}$ & $\begin{array}{c}\text { неутеплена } \\
\text { частина }\end{array}$ & 144456,01 & $\begin{array}{l}Q_{t r} \\
=157789,4\end{array}$ & $Q_{t r}=192307,7$ & $Q_{t r}=168762,16$ \\
\hline $\begin{array}{l}\text { Відхилення від } \\
\text { значення втрат т } \\
\text { (неутеплена част }\end{array}$ & $\begin{array}{l}\text { ктичного } \\
\text { Ілоти, \% } \\
\text { на) }\end{array}$ & $14,4 \%$ & $6,5 \%$ & $14,0 \%$ & - \\
\hline
\end{tabular}

\section{Висновки}

Проведено дослідження теплових втрат 3 урахуванням різних методик визначення теплозахисних властивостей зовнішніх непрозорих огороджень. Показано, що урахування теплопровідних включень навіть для споруди без складних конструктивних рішень огороджень призводить до збільшення тепловтрат в розмірі до $14 \%$, внаслідок чого може змінитися клас енергоефективності будівлі, тому поширена практика енергоаудиторів під час визначення енергопотреби будівлі спрощувати подібні розрахунки не $\epsilon$ виправданою.

\section{Список використаної літератури}

1. Теплова ізоляція будівель: ДБН В.2.6-31:2016. - [Чинні від 2017-05-01] // Міністерство регіонального розвитку, будівництва та житлово-комунального господарства України. - К.: Укрархбудінформ, 2016. - 33 с. - (Державні будівельні норми України)

2. Методи вибору теплоізоляційного матеріалу для утеплення будівель / ДСТУ Б В.2.6-189:2013 [Національний стандарт України] - К.: Мінрегіон України, 2013, - 55 с.

3. Енергетична ефективність будівель. Метод розрахунку енергоспоживання при опаленні, охолодженні, вентиляції, освітленні та гарячому водопостачанні / ДСТУ Б А.2.2-12:2015 [Національний стандарт України] - К.: Мінрегіон України, 2015, - 203 с.

4. Розрахункові параметри мікроклімату приміщень для проектування та оцінки енергетичних характеристик будівель по відношенню до якості повітря, теплового комфорту, освітлення та акустики / ДСТУ Б ЕN 15251:2011[Національний стандарт України] - К.: Мінрегіон України, 2012, - 71 с. 


\title{
ISSN 1813-5420 (Print). Енергетика: економіка, технології, екологія. 2017. № 4
}

5. Метод визначення питомих тепловтрат на опалення будинку / ДСТУ Б В.2.2-21:2008 [Національний стандарт України] - К.: Мінрегіон України, 2009, - 29 с.

6. Метод визначення опору теплопередачі огороджувальних конструкцій/ ДСТУ Б В.2.6-101:2010 [Національний стандарт України] - К.: Мінрегіонбуд України, 2010, - 84 с.

7. EN 12831:2003 (E) Heating systems in buildings - Method for calculation of the design heat load. CEN, 2003. -76.

\author{
M. Shovkalyuk, Cand. Sc. (Eng.), Assoc. Prof.., ORCID 0000-0002-1898-3493 \\ S. Zimenko, Msc., ORCID 0000-0003-4151-0931 \\ National Technical University of Ukraine "Igor Sikorsky Kyiv Polytechnic Institute"
}

\section{ANALYSIS OF HEAT LOSS THROUGH WALLING WITH THE ACCOUNT OF DIFFERENT METHODS OF ESTIMATION OF HEAT-SHIELDING PROPERTIES}

The aim is to study the heat flow and analysis of heat loss from the heated space. The problem is analyzed in the article and the specific object of the study is considered, its design features and specific thermally conductive inclusions are considered using various calculation methods. Methods of modern up-to-date standards of Ukraine for calculating the heat-shielding properties of the enclosing structures of a building with allowance for thermal inclusions and without them are considered.. Based on the results of the study, differences were identified between the methods, the main parameters were determined, the differences between the approaches. The result of the study is the conclusion that thermal inclusions exert a significant influence on the overall level of heat-shielding properties of the walling and the importance of the correct choice of the calculation method taking into account existing data on the object. In the conclusions it is established that the method of estimating heat losses with allowance for thermal inclusions allows more accurately to estimate the heat-shielding properties of the investigated section.

Keywords: walling, thermal protection, thermally conductive inclusions

\section{References}

1. Construction of buildings and facilities. Thermal insulation of buildings: DBN V.2.6-31:2016. - [Valid from 01.04.2017] // Ministry of construction, architecture and housing and communal services of Ukraine. - Kyiv, 2016. - 33 p. - (State Building Standards of Ukraine), (Ukr).

2. Methods for choosing of insulation material for insulation of buildings: DSTU B V.2.6-189:2013. [Valid from 01.01.2014] // Ministry of construction, architecture and housing and communal services of Ukraine. - Kyiv, 2014. - 55 p. - (State Standards of Ukraine), (Ukr).

3. The energy efficiency of buildings. The method of calculating the energy consumption for heating, cooling, ventilation, lighting and hot water supply: DSTU B A.2.2-12:2015. - [Valid from 01.01.2016] //

Ministry of construction, architecture and housing and communal services of Ukraine. - Kyiv, 2011. - 203 p. (State Standards of Ukraine), (Ukr).

4. Indoor environmental input parameters for design and assessment of Energy performance of buildings addressingindoor air quality, Thermal environment, lighting and acoustics: DSTU B EN15251:2011. - [Valid from 01.01.2013] // Ministry of construction, architecture and housing and communal services of Ukraine. - Kyiv, 2012. - 71 p. - (State Standards of Ukraine), (Ukr).

5. Buildings and structures. Method for determination of specific heat consumption for buiding heating: DSTU B V.2.2-21:2008. - [Valid from 01.06.2009] // Ministry of construction, architecture and housing and communal services of Ukraine. - Kyiv, 2009. - 29 p. - (State Standards of Ukraine), (Ukr).

6. Constructions of buildings and structures. Method for determination of thermal resistance of building envelopes: DSTU B V.2.6-101:2010. - [Valid from 01.10.2010] // Ministry of construction, architecture and housing and communal services of Ukraine. - Kyiv, 2010. - 84 p. - (State Standards of Ukraine), (Ukr).

7. EN 12831:2003 (E) Heating systems in buildings - Method for calculation of the design heat load. CEN, 2003. - 76. 
УДК 697.1

Шовкалюк М.М., канд. техн. наук, доц., ORCID 0000-0002-1898-3493

Зименко С.B., магистр, ORCID 0000-0003-4151-0931

Национальный технический университет Украины «Киевский политехнический институт имени Игоря Сикорского»

\section{АНАЛИЗ ТЕПЛОПОТЕРЬ ЧЕРЕЗ ОГРАЖДЕНИЯ С УЧЁТОМ РАЗНЫХ МЕТОДОВ ОЦЕНКИ ТЕПЛОЗАЩИТНЫХ СВОЙСТВ}

Целью работы является исследование тепловых потоков и анализ тепловых потерь из отапливаемых помещений. В статье проанализирована проблематика вопроса, и принят к рассмотрению конкретный объект исследования, рассмотрены его конструктивные особенности и конкретные теплопроводные включения с помощью различных методик расчета. Рассмотрень методики действующих современных стандартов Украины по расчету теплозащитных свойств ограждающих конструкций здания, с учетом тепловых включений и без них. По результатам исследования определень различия между методиками, рассчитаны ключевые параметры, определены различия между подходами. Результатом исследования является вывод о значительном влиянии тепловых включений на общий уровень теплозащитных свойств ограждающих конструкций и важность правильного выбора методики расчета с учетом существующих данных об объекте. В выводах определено, что методика оченки тепловых потерь с учетом тепловых включений позволяет более точно оченить теплозащитные свойства участка исследования.

Ключевые слова: ограждающие конструкции, тепловая защита, теплопроводные включения.

\section{ОЦЕНКА ЭФФЕКТИВНОСТИ ОТДАЧИ ТЕПЛОТЫ ТЕПЛОАККУМУЛИРУЮЩИМИ ЭЛЕМЕНТАМИ ЭЛЕКТРОТЕПЛОВОГО АККУМУЛЯТОРА}

Данные, полученные в результате проведения экспериментальных исследований динамических характеристик теплоаккумулирующих элементов из магнезита с каналами щелевидной формы, а также теплоаккумулирующих элементов из шамота с воздушными каналами круглой формы в режимах заряда и отдачи теплоты электротеплового аккумулятора (ЭТА), были использованы для оценки эффективности аккумулирования и отдачи теплоты теплоаккумулирующими элементами ЭТА. Определены средний коэффициент теплоотдачи от наружной поверхности корпуса ЭТА $\alpha_{H_{-} c p}$, а также коэффициент теплоотдачи в каналах теплоаккумулирующих элементов из магнезита и шамота при

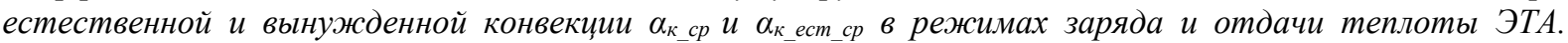
Показана динамика отдачи теплоты в каналах теплоаккумулирующих элементов $Q_{\kappa}$ ср и общей отдачи теплоты $Q_{0}$ за весь цүикл работы ЭТА. Были также получены аналитические выражения для определения избыточной температуры теплоаккумулирующих элементов из шамота и магнезита в режиме отдачи теплоты ЭТА путем аппроксимации полученных значений темпа охлаждения методом наименьших квадратов с использованием экспоненциальной функиии.

Ключевые слова: электротепловой аккумулятор, теплоаккумулирующий элемент, режимы заряда и отдачи теплоты, темп нагрева и охлаждения, шамот, магнезит, коэффициент теплоотдачи, температурный напор, распределение температур, тепловые характеристики.

(C) А.В. Хименко, 2017 